Вања Јовановић

Марија Нисић

Ана Цветановић

Универзитет у Београду

Филолошки факултет

Катедра за славистику

jovanovic29v@gmail.com
УДК 811.163.41'27

https://doi.org/10.18485/slavistika.2021.25.2.24

Оригиналан научни рад

примљено 25.8.2021.

прихваћено за штампу 6.10.2021.

\title{
О ДИНАМИЦИ ПРОМЕНА У ЈЕЗИЧКОЈ СЛИЦИ СТВАРНОСТИ КРОЗ ПРИЗМУ ВЕРБАЛНИХ АСОЦИЈАЦИЈА (на примеру српског језика)
}

На основу материјала аутентичног асоцијативног експеримента из 2020. године и Асоцијативног речника српског језика (2003) извршена је анализа језичке слике света Срба с циљем испитивања тезе о тзв. језгру језичке свести, које је представљено са 30 најфреквентнијих реакција на задате лексеме-стимулусе. У истраживању се полазило од претпоставке да су асоцијације узроковане друштвеним приликама и у складу с тим постављено је питање колико је стабилно језгро језичке свести. У реакцијама из оба периода, најзаступљенији су појмови који се односе на универзалне људске вредности, али су уочена и извесна одступања. Услед ситуације са корона вирусом и принудном изолацијом, у језгру из 2020. године су махом заступљене лексеме које се односе на природу, док се 2003. године у свести Срба још увек чувало сећање на ратове, те су фреквентне реакције са негативном конотацијом: страх, смрт, туга, бол. Фреквентност појединих реакција указује на специфичне одлике језгра језичке свести Срба у поређењу с другим словенским народима.

Кључне речи: когнитивна лингвистика, вербалне асоцијације, асоцијативни експеримент, језичка слика стварности, језичко језгро свести.

Based on the material of the authentic association experiment from 2020 and the Associative Dictionary of the Serbian Language (2003), an analysis of the Serbian linguistic world image was carried out with the aim of testing the thesis of the so-called core of linguistic consciousness, that is shown with 30 most frequent reactions to given stimuli. The research was started with the assumption that associations are affected by social circumstances and in accordance with that we question the stability of the core of language consciousness. In the reactions from both periods, the terms that refer to universal human values are the most common, but certain discrepancies have also been noticed. Due to the situation with the coronavirus and forced isolation, in the core from 2020, lexemes related to nature were mostly present, while in 2003 the memory of wars was still kept in the consciousness of the Serbs, consequently reactions with negative connotation such as fear, death, sorrow, pain were frequent. The frequency of certain reactions indicates the specific features of the core of linguistic consciousness of Serbs in comparison with other Slavic people.

Keywords: cognitive linguistics, verbal associations, association experiment, linguistic image of reality, linguistic core of consciousness.

\section{Увод}

Језичка слика стварности (JCC) представља комплекс судова о свету, људима, стварима и догађајима, који су субјективни, али и интерсубјективни јер постају друштвено прихваћени (Бартмињски 2011: 46). Вербалне асоцијације се сматрају поузданим средством проучавања тако схваћене језичке слике света 
јер су претежно стереотипне природе, односно засноване на интерсубјективним асоцијативним представама. Као резултат слободних асоцијативних експеримената, крајем седамдесетих година прошлог века настају први асоцијативни речници словенских језика, који су и данас широко заступљени у лингвистичкој славистици (Курч 1967; Бутенко 1979; Цітова 1981; Балтова и др. 2003; Мартінек 2007 и др.). Међу њима се посебно издваја Руски асоцијативни речник Јурија Караулова и његових сарадника (Караулов и др. 1994, 1996, 1998, 2002), као и Словенски асочијативни речник групе аутора (Уфимцева и др. 2004), у којем су прикупљени резултати асоцијативних истраживања за четири словенска језика - белоруски, бугарски, руски и украјински. Истраживање Јурија Караулова и његових сарадника поставља темеље за даља систематична проучавања вербалних асоцијација у лингвистичкој славистици, а примена вербалних асоцијација у когнитивнолингвистичким и сродним истраживањима постаје незаобилазни део методологије у школама етнолингвистичког и лингвокултуролошког усмерења, поред етимолошке, контекстуалне, паремиолошке, концептуалне и интерпретативне анализе.

Погодност материјала из асоцијативних речника за етнолингвистичка и лингвокултуролошка истраживања, као и за реконструкцију концепата и стереотипа, показана је у великом броју србистичких и славистичких радова (в. Поповић 2008, Стефановић 2012; Авагјан 2017; Пауновић Родић 2019; Ристић, Лазић Коњик 2020). Асоиијативни речник српског језика, који су приредили Предраг Пипер, Рајна Драгићевић и Марија Стефановић, појавио се 2003. године, а други том Обратни асочијативни речник српског језика, објављен је 2011.

Проучавање вербалних асоцијација из различитих аспеката заступљено је у домаћој лингвистици у оквиру различито усмерених истраживања - лексичко-семантичких (в. Драгићевић 2003, 2010; Пипер 2003, 2006), лингвокултролошких (Раздобудко-Човић 2006; Стефановић 2008, 2012, 2013, 2015; Даути 2012), когнитивнолингвистичких (Поповић 2008, 2017; Авагјан 2017; Пауновић Родић 2019), теолингвистичких (Кончаревић 2015, 2015a), етнолингвистичких (Ристић, Лазић Коњик 2020) и др.

За ово истраживање, као грађа послужио је Асочијативни речник српског језика ${ }^{1}$ (2021), који је израђен на основу резултата аутентичног асоцијативног експеримента. Експеримент је реализован 2020. године на Катедри за славистику Филолошког факултета у Београду у склопу колективног научноистраживачког пројекта „Језичка слика света Срба и других словенских народа кроз призму вербалних асоцијација" под руководством проф. др Људмиле Поповић. ${ }^{2}$ За потребе израде овог речника је анкетирано 795 говорника српског језика. ${ }^{3}$

${ }^{1}$ У наставку текста овога радакористиђемо такође скрађеницу АРСЈ.

${ }^{2}$ Овом приликом бисмо желели да искажемо искрену захвалност свим колегама, студентима Катеде за славистику Филолошког факултета у Београду, који су учествовали у реализацији овог пројекта на прикупљању асоцијативних анкета. Посебну захвалност дугујемо проф. др Људмили Поповић, под чијим руководством је настао овај рад. За све евентуалне пропусте, наравно, одговорност сносе сами аутори.

${ }^{3}$ У изради речника, поред аутора овог рада, учествовали су колеге са Катедре за славистику Филолошког факултета у Београду: Матија Васовић, Анђелија Ђорђевић, Симка 
Други део грађе чине асоцијативни речници српског језика из 2003. и 2011. (Пипер и др. 2003; Драгићевић и др. 2011), који су састављени на основу резултата експеримента из 2002-2003. године, када је било анкетирано 800 испитаника по речи-стимулусу.

Како је број испитаника у оба експеримента приближно исти, полазили смо од претпоставке да би поређење асоцијација из 2002-2003. и 2020. године могло пружити релевантне одговоре на питања која смо поставили у нашем раду да ли је језичка слика једног народа подложна променама са временом, каква је динамика тих промена, да ли су оне могуће у једном краћем периоду од 20 година, и, ако јесте, који су фактори кључни у таквим променама.

Како би се могле упоредити промене у језичкој слици света, одлучили смо да издвојимо најфреквентније асоцијације у оквиру оба експеримента као показатељ оног њеног дела који би се могао условно одредити као језгро језичке свести (JJC) једног народа. Термин језгро језичке свести (ядро языкового сознания) увела је Н. В. Уфимцева (Уфимцева и др. 2004: 6). Он подразумева 30 најфреквентнијих асоцијација које се јављају као одговори на све стимулусе у оквиру једног асоцијативног експеримента. У свом раду користићемо овај термин. Како истиче Р. Драгићевић, ,језгро језичке свести морало би бити непроменљиво и стабилно, а списак од ових 30 лексема у мањој или већој мери био би друкчији да су стимулуси били друкчији" (в. Драгићевић 2010: 131). У нашем истраживању, између осталог, испитаћемо и ову претпоставку јер су се стимулуси у оквиру експеримента 2002-2003. и 2020. разликовали, с обзиром на то да је старији речник садржао 600 стимулуса (6 анкета од по 100 стимулуса), док новонастали 108, од тога се подудара 45 стимулуса.

Главни циљ нашег истраживања је да, полазећи од систематизоване грађе аутентичног асоцијативног експеримента и АРCJ-a, сагледамо и упоредимо језичку слику стварности код Срба из 2002-2003. и 2020. године. Имајући у виду да се околности у друштву мењају, а да су те промене уочљивије након одређеног периода, полазна хипотеза у овом истраживању је претпоставка да ће се асоцијације из 2003. и 2020. незнатно разликовати, а да ће се у већем делу најфреквентније асоцијације подударати без обзира на различите стимулусе, тј. настојаћемо да докажемо тезу о одрживости појма језгра језичке свсети.

Наш задатак је такође у томе да упоредимо најфреквентније асоцијације које су се јавиле у оба поменута експеримента са најфреквентнијим асоцијацијама код других словенских народа, које су издвојене у Словенском асоиијативном речнику (Уфимцева и др. 2004: 6, 7).

Тиме ћемо одговорити на питање да ли се може говорити о заједничком језгру језичке свести Словена или су разлике међу JJC појединих словенских народа толико велике да о томе не може бити речи.

Ђурић, Тијана Илић, Александра Јанковић, Невена Јарић, Ања Клипа, Катарина Теофиловић, Анђела Шимшић. 


\section{Анализа}

Анализа динамике промена у језичкој слици стварности путем поређења вербалних асоцијација изложена је у три дела. У првом делу приказаћемо најфреквентније реакције које су се јавиле у оба експеримента. У другом делу издвојићемо разлике међу најфреквентнијим реакцијама које су се јавиле код испитаника 2003. и 2020. године и испитаћемо у чему се оне састоје из аспекта концептуализације стварности. Трећи део ће садржати осврт на поједине специфичности које се јављају међу најфреквентнијим асоцијацијама како би се указало на утицај стереотипних схватања у друштву на реакције испитаника.

Први део истраживања започиње анализом првих пет најучесталијих реакција које најбоље одражавају стереотипне представе једног народа и, на неки начин, оно што је за његове представнике најважније. Већ на први поглед постаје уочљиво да се четири исте реакције јављају у првих пет најфреквентнијих асоцијација из оба експеримента (2003. и 2020): човек, срећа, љубав и живот. Из овога можемо закључити да, иако је прошло скоро 20 година између два експеримента, испитаницима у Србији прво падају на памет појмови које можемо одредити као опште људске вредности. Иако су стимулуси били различити, ове асоцијације убедљиво предњаче у оба експеримента, што потврђује тезу о стабилности језгра језичке свести.

Интересантно је да се међу најфреквентнијим асоцијацијама из 2003. на првом месту налазила реакција живот, док се 2020. нашла реакција човек. Потоња асоцијација се јавља као најфреквентнија и код других словенских народа. Рецимо, у Словенском асоцијативном речнику (Уфимцева и др. 2004), на првом месту по броју реакција код четири словенска народа - руског, белоруског, украјинског и бугарског, такође се налази реакција човек. Занемарљиве разлике у учесталости, а самим тим и у рангу који заузимају асоцијације, нису пресудне за тумачење значаја појединих концепата у језичкој слици стварности; важна је чињеница да су оне најучесталије. Реакција човек сведочи о антропоцентричном погледу на свет, као и о својеврсном егоцентризму, тј. окренутости човека у доживљавању света првенствено самом себи, као заједничким одликама језичке слике света свих Словена.

Поред ове реакције, која је неутрална по свом значењу, међу најучесталијим реакцијама из 2003. у првих пет налази се и асоцијација ја, која потврђује претпоставку о наглашеној пажњи савременог човека према самом себи и свом деловању. Овде ваља указати на реакцију породица, која спада међу најфреквентније у екперименту из 2020. и стоји насупрот егоцентричном ја из 2003. године као поштован и цењен вид родбинске заједнице.

Није необично да се међу најфреквентнијим реакцијама јавила и лексема живот. Како српски говорници поимају овај апстрактан појам постаје јасно када се анализирају реакције на стимулус живот, који је био заступљен у оба експеримента. Према резултатима експеримената из 2003. (Пипер и др. 2003) и 2020. живот је окарактерисан као срећан, леп, радостан и дуг (уп. реакције на стимулус живот из експеримента 2020: срећа (49), смрт (41), ${ }^{4}$ дуг (42), леп

4 За потребе анализе нисмо узимали у обзир реакције које представљају антоним стимулусу, и обрнуто. Сматрамо да је то лексички механизам који не захтева додатно тумачење, 
(39), радост (29); реакције на исти стимулус из АРСЈ, 2003: смрт (135); срећа (57); радост (32); леп (30); лепота (26)).

У пет најучесталијих реакција према резултатима експеримента из 2020. године спада и реакција сунце, која нас уводи у други део наше анализе. У 30 најучесталијих реакција из 2020. јавило се чак шест асоцијација које се односе на природу: сунщее (682), дан (446), вода (432), дрво (423), снег (281), ноћ (281), за разлику од експеримента из 2003. у ком нема ниједне сличне реакције међу најучесталијих 30. Претпостављамо да су на овакво стање утицале околности у којима је спроведен асоцијативни експеримент 2020. године, која је обележена епидемијом, изазваном вирусом COVID-19, и њеним сузбијањем путем увођења карантина и инсистирања на кућној изолацији становништва. С тим у вези, претпостављамо да се код испитаника јавила потреба за природом, изласком у шетњу по лепом времену, а самим тим и повећана осетљивост на такве факторе.

Најучесталије асоцијације из експеримента 2003. године одражавају другачије историјске околности, што се види по томе да се међу асоцијацијама може наћи велики број негативно конотираних реакција - чак 10 од најфреквентнијих 30 чине лексеме: досада, ништа, страх, глупост, лаж, рат, смрт, туга, лоше, бол .

Асоцијативни експеримент на основу ког је образован Асоцијативни речник српског језика из 2003, односно Обрнути асочијативни речник српског језика из 2011, спроведен је почетком двехиљадитих, тј. у периоду ближем НАТО бомбардовању и ратовима уопште, те, претпостављамо, тиме се може објаснити нешто „мрачнија” језичка слика коју очитавамо из ових реакција. Истаћи ћемо да се на стимулус губици у речнику из 2003. као фреквентне јављају реакције pam (52) и ратни (7), док се на сличан стимулус - губити у експерименту из 2020. ниједном нису јавиле наведене реакције, већ се овај глагол везује за новаи (31), живце (25), време (22), игру (14), килажу (9). У целокупном асоцијативном експерименту из 2020. нема реакције НАТО, а асоцијација бомбардовағе се јавила само два пута.

У прилог констатацији о утицају друштвених околности у којима се одвија експеримент на учесталост одређених асоцијација иде чињеница да се у експерименту из 2020. године јавља више реакција које су позитивно конотиране: суние, дете, породииа, дан, радост, мир, брат, пријатель, лепота, мајка, снага. О концептуализацији ових појмова у језичкој слици Срба сведоче резултати асоцијативног експеримента из 2020. године: дете - мало (108), игра (49), срећа (47); породица - срећа (82), љубав (79), дом (52); дан - сунце (306), светлост (73); радост - срећа (238), осмех (39); пријатељ - друг (90), добар (40), подрика (39); мајка - љубав (129); снага -моћ (110), мишићи (109), ум (52), воља (37); суние $\leftarrow^{5}$ светлост (187), јутро (137); рођени $\leftarrow$ брат (306); лепота $\leftarrow$ лице (120); мир Ł село (58), вече (35), река (30).

Упоредна анализа реакција у оба асоцијативна експеримента (2002-2003 и 2020), на идентичне стимулусе (бео, богат, велик, викати, вода, врата, глава, глуп,

нити даје додатне информације при анализи динамике промена JCC.

5 Знак ' $\leftarrow$ ' означава да је у питању податак из обратног асоцијативног речника, када се посматра учесталост јављања одређене реакције у речнику уз различите стимулусе. 
говорити, губиции/губити, ${ }^{6}$ дан, дете, добар/добро, живот, заједно, зелен, кћерка/ кћи, леп, лище, лош, љубав, мали, мама/мајка, мислити, младост/млад, много, муж, надати се, непријатељ, нов, новаи, обећање/обећати, очи, паметан, пиће/пити, појести/јести, породични/породича, праведан/правда, пријатељ, прст/прсти, радост, родбина, рођени, рука/руке, смрт, споменик, срећа, стар, стидљив/стид, уста, хлеб, хтети, ирвени, ирн, чика, шкрт) показује да се у експерименту из 2002-2003. на пет стимулуса (бео, говорити, обећање/обећати, радост, срећа) чешће јављају негативно конотиране реакције, док код осам стимулуса (љубав, муж, надати се, појести/јести, праведан/правда, родбина, стар, ирн) постоји незнатна разлика у укупном броју негативно конотираних реакција или је њихов број приближно исти. Међутим, ако посматрамо само најфреквентније реакције на наведене стимулусе, уочавамо да су оне у оба експеримента исте, са занемарљивом разликом у броју јављања, што опет потврђује нашу полазну претпоставку о томе да језгро језичке свести остаје већим делом стабилно и непроменљиво, а да су промене заступљене у мањој мери (в. Прилог 1).

Као најзначајније разлике које сведоче о променама у језичкој слици кроз време, чак и током релативно краћег периода, могу се истаћи следеће: реакције на стимулус бео показују да су Срби 2003. везивали белу боју претежно за смрт и болест, а знатно мање за венчање или невиност, што је случај у експерименту из 2020. На стимулус говорити, на пример, 2020. испитаници су најчешће одговарали реакцијом истина (83), за разлику од 2003, када се у центру асоцијативног поља овог стимулуса није нашла поменута реакција. Штавише, као асоцијација на стимулус истина 2003. јавља се негативно конотирани глагол брбљати (29).

На лексему-стимулус обећаље, односно обећати, најзаступљенија реакција 2003. је лудом радовағе, а 2020 - глагол испунити. Изрека обећағе лудом радовање подразумева да се обећање неће испунити и самим тим схватање обећања 2003. године у потпуности је супротно оном које се испољило у асоцијативном експерименту из 2020.

Важно је истаћи и чињеницу да се на стимулус смрт 2003. јавило 15 позитивних реакција, међу којима су: живот, бело, мир, спас, рођење, анђео, Бог, идеал, храброст, лака, љубав, нада, спасење, спокој, смиреност, док се 2020. јавило чак 22 позитивне реакције на исти стимулус: живот, спокој, одмор, ослобођење, нов почетак, рај, слобода, спас, Бог, почетак, радост, други живот, не плашити се, одмарање, олакшање, осмех, победити, рођење, слатка, смиреност, херојска, часна. Међу реакцијама на стимулус смрт 2003. среће се и асоцијација pam, што није случај са реакцијама на исти стимулус 2020.

Примећено је да се у Обратном асоиијативном речнику српског језика 7 (Драгићевић и др. 2011) више пута јавила реакција дан на стимулус сив (49). У истом речнику реакција дете се нашла међу фреквентнијим на стимулус побачај (33), а код стимулуса дете у АРСЈ (Пипер и др. 2003) могла се срести и асоцијација мртво. Са друге стране, у експерименту из 2020. забележена је нешто блаже конотирана асоцијација на исти стимулус - нежељено.

\footnotetext{
${ }^{6}$ Као сличне разматрали смо и оне стимулусе који припадају истом деривацијском гнезду или се могу посматрати као апсолутни синоними, нпр. губици и губити, мама и мајка итд.

7 У даљем тексту ОАРСЈ.
} 
Претпостављамо да се услед сећања на тек прохујале ратове у АРСЈ из 2003. реакција добро јавља тек на 26. месту у односу на укупан број свих реакција (280 јављања) док се у експеримену из 2020. иста асоцијација налази на деветом месту по броју јављања (укупно 457 пута). У прилог овом запажању истаћи ћемо и чињеницу да се у експерименту из 2020. реакција добро јавља као знатно фреквентнија асоцијација на стимулус дело (166). Стимулус дело, према подацима из 2003, првенствено асоцирало на уметност (87), док се асоцијација добро уопште није јавила, али реакција ружно (3) јесте.

Већ је било напоменуто раније да се међу 30 најфреквентнијих реакција из 2003. јавља ја, док се 2020. међу првих 30, тј. у језгру језичке свести (JJC), налази породица, што показује да је фокус пребачен са појединца на заједницу. До сличних закључака може се доћи и анализом учесталости следећих асоцијација: дете, брат, жена, мајка, који се јављају у ЈЈС из 2020. Занимљиво је да у Србији породица не представља само њене најуже чланове. О томе сведочи чињеница да је реакција породица најфреквентија асоцијација на стимулус родбина (103).

Реакција мајка (90), која се нашла у JJC према резултатима експеримента из 2020, потврђује посебан значај мајке у српској породици (поређења ради, реакција отац се није нашла међу 30 најучесталијих). Ова асоцијација се најчешће јављала на стимулус жена. ${ }^{8}$ Истраживање Стефане Пауновић Родић (2019) показало је да се код Срба жена првенствено везује за родну улогу мајке, а резултати нашег експеримента потврђују њено запажање. Како је наведено у цитираном истраживању (Пауновић Родић 2019), на стимулус јака жена у асоцијативном речнику Словака, најбројнија је реакција мајка, док су реакције које упућују на физички изглед јаке жене много ређе: бицепс, мишићи, бодибилдерка. Ови подаци јасно говоре да и код Словака мајка има важну улогу у породици, где представља борбену жену, односно особу која одржава породицу и највише брине о укућанима.

Што се тиче нашег истраживања, сасвим је очекивано да се асоцијација мајка јавља на позитивне стимулусе, попут љубав (7), снага (9), породица (7), као и да се на стимулус мајка јаве реакције љубав (129), брига (26), нежност (15), загрљај (13). Слични су резултати асоцијативног експеримента и код Словака, где налазимо на следеће асоцијације на исти стимулус: дивна, идеална, савршена, краљиияа (Ibid.).

Напоменућемо да се на стимулус мајка и 2003. и 2020. године јављају само позитивне реакције, што сведочи о стабилности позиције овог концепта у језгру језичке свести српског народа и његовог значаја у колективној представи.

Реакција жена у асоцијативном експерименту из 2020. нашла се у анкети уз стимулусе муж и мушкарац. На стимулус муж у експерименту из 2020. најфреквентије асоцијације су: жена (121), брак (74) и отац (38). Иако се сти-

8 У асоцијативном експерименту из 2020. два основна значења лексеме жена - „особа женског пола“ и „супруга“ раздвојена су тако тако што се тај стимулус јавља двапут једном одмах после стимулуса мушкараи, а други пут одмах иза стимулуса муж. Тиме се испитаницима имплицитно предочавала разлика. Међутим, резултати експеримента сведоче да се родна улога супруге чврсто везује за особу женског пола код Срба јер су се у оба слуачја подједнако често јављале реакције муж, брак, деца и сл. 
мулус муж, као што видимо, везује за брак и оца, његова улога у колективној свести Срба није у потпуности дефинисана, о чему сведочи чињеница да се у оба речника јавио подједнако велики број негативних реакција на овај стимулус. Навешћемо неке од фреквентнијих негативних реакција: обавеза (13), љубавник (7), далеко (5), досада, швалер (3), будала, никад, роб, смор (2) (2003); обавеза, швалер (3), бес, геј, досада, лош, туђ (2), давеж, далеко (1) (2020).

На стимулус мушкараи јављају се реакције снага (131), брада (34), као и одело, бркови, мишићи, рамена, кравата, панталоне, кошуља, стена, висок као одлике физичког изгледа, а у ОАРСЈ (Драгићевић и др. 2011) асоцијација мушкарац најчешће се јавила на стимулусе страстан (13), лепотан (12) и муж (10) и само једном на стимулус отац, што сведочи о слабом повезивању родне улоге оца са лексемом мушкарац, тј. потпуно супротно од концептуализације жене у језичкој слици света Срба.

У АРСЈ (Пипер и др. 2003) на стимулус отац 9 јавља се реакција љубав (38), али и ауторитет (21), односно глава породице (20), док се у експерименту 2020. и на жену гледа као на стуб (11), односно стуб куће (9). Као што је истакла Стефана Пауновић Родић, Срби, али и Словаци, на мајку гледају као на борбено, јако и самостално биће: „Осим што жена своју снагу показује издржљивошћу и способношћу да обавља све традиционално женске послове, на челу с мајчинством, можемо рећи да је снага жене повезана у првом реду са самосталношћу, тј. еманципацијом, и то финансијском. Важно је да приметимо и наизглед суптилну, а веома значајну разлику између концепта (мушке или опште) снаге и моћи и оне снаге и моћи која се приписује женама: ова друга искључује насиље” (Пауновић Родић 2019: 179). Физичка снага се јавља као реакција на стимулус мушкарац у асоцијативном експерименту из 2020. Снага коју поседује жена није физичка. Она се односи на њену борбу за породицу, брижност према укућанима, што се огледа у реакцији „стуб породице”.

У оквиру асоцијативног поља на стимулус мушкараи (2020) могу се наћи и негативно конотиране реакције: зло, лажов, превара, туча, безосећајан, наспрам позитивно конотираних асоцијација змај и херој, које се јављају на стимулус жена.

Трећи део истраживања усмерен је на изношење запажања која се односе на промене у структури ЈСС код Срба.

Након указивања на промене у вредновању породице и појединца, у складу са резултатима асоцијативних експеримената из 2003. и 2020, желели бисмо скренути пажњу на промене у приступу материјалним вредностима код просечног члана српске етносоциокултурне заједнице. О томе да је до таквих промена дошло, рецимо, сведочи чињеница да се међу 30 најфреквентнијих реакција 2020. нашла асоцијација ауто (339). С обзиром на то да је ауто уједно и најфреквентнија асоцијација на стимулус нов (157), очигледно је да је овај квалитет код аутомобила обележен, тј. нов аутомобил је нешто што представља посебну вредност у складу са резултатима експеримента.

Новац игра важну улогу у животу просечног човека, што потврђује заступљеност ове реакције у JJC у оба експеримента (2003. и 2020). Поређење

\footnotetext{
${ }^{9}$ Стимулус отац није укључен у експеримент из 2020.
} 
структуре ова два језгра такође показује да се 2020. у њему појавиле реакције храна и ручак, које се не налазе међу најфреквентнијим 2003. Реакција храна се код Срба највише јавила на стимулусе јести (143) и хлеб (97), а ручак на стимулус сто (203), и то као најфреквентнија реакција на овај стимулус, иако је лексема полисемична и може означавати било коју врсту стола, односно могла се тумачити и као хомоним који је везан за квантификацију. Наведени резултати сведоче не само о значају хране у српској култури, већ наводе на констатацију да су се услед неповољних прилика у јавном животу (пандемије) Срби окренули породици и својеврсном хедонизму.

Значајно је напоменути да смо, имајући у виду распоред и фреквенцију асоцијација у асоцијативним речницима, запазиле да се у највећој мери очувала асоцијативна веза синонима и антонима, док су све промене настале као последица наведених друштвених промена и историјских догађаја. Развој науке и технике, као и модернизација свакодневног живота допринели су такође и учвршћивању страних речи, тј. позајмљеница у спрском језику, а самим тим су се и дате лексеме јавиле као асоцијације на задате стимулусе. Тако се у експерименту из 2020. нашла реакција инстаграм, на стимулус леп, што није случај у АРСЈ (Пипер и др. 2003). Ова чињеница је сасвим логична будући да је инстаграм као друштвена мрежа креиран 2010. У асоцијативном експерименту из 2020. нашла се и реакција ајфон, на стимулус надати се, што није могао бити случај 2003. јер се ајфон појавио 2007. године. Ове чињенице сведоче о томе да су промене у структури ЈСС једног народа условљене променама у самом друштву.

Стереотипи су упрошћене, типичне и друштвено утврђене представе о различитим сегментима стварности (в. Поповић 2008). Најфреквентније реакције на стимулус жена у асоцијативном експерименту 2020. су: мајка, муж, лепота, брак. На стимулус мушкарац најфреквентнија асоцијација је снага. Будући да наведених стимулуса није било у АРCJ (2003), навешћемо чињенице из ОАРСЈ (2011), где се реакција жена јавила на стимулусе: муж, вољена, моћна, леп, мама, нежан, љубав. Реакција муж се јавила на следеће стимулусе: јачи, груб, храбар, нежан, страстан, лепотан. Наведене реакције указују на стереотипно схватање улоге жене и мушкарца у савременом српском друштву. Концептуализација мушкарца као припадника јачег, снажнијег пола и жене као припаднице лепшег пола - слабијег и нежнијег, стабилна је, што потврђују како ранија истраживања ове проблематике (Поповић 2008; Пауновић Родић 2019) тако и резултати оба асоцијативна експеримента (2003. и 2020).

Стереотипизацији је подложно схватање и других улога жене у савременом друштву, о чему сведоче реакције на стимулус бака, међу којима су старост и храна.

Судећи по резултатима асоцијативних речника, Срби сматрају да са новцем, долази и моћ, те се на стимулус новац, моћ јавила у прве две најфреквентије асоцијације у асоцијативним речницима из 2003. и 2020. године. Међутим, у оба речника се срећу и стереотипне реакције на стимулус новащ: прљаво, зло, мито, похлепа.

Стимулус родбина везује се за славу, која се као асоцијација нашла међу најфреквентијим реакцијама у оба асоцијативна експеримента. Ова асоцијација 
се везује за традицију и породичне вредности јер слава представља прилику да се једном годишње родбина на једном месту и окупи. Међутим, код Срба се на родбину понекад гледа у негативном контексту, те су се у речницима нашле и следеће, не тако фреквентне, али речите реакције: досадна, свађа, љубомора.

Значајно је истаћи и стереотипизацију људских особина. У асоцијативим речницима (АРСJ, ОАРСJ) међу првима се нашла асоцијација човек као реакција на стимулусе глуп и паметан, поред реакција (паметан) пас и (глуn) магарац.

\section{Закључак}

На основу поредбене анализе језгра језичке свести Срба, реконструисаног током асоцијативних експеримената који су реализовани 2002-2003. и 2020, долазимо до закључка да у појединим аспектима постоје квалитативне и квантитативне промене у JJC Срба, док су у осталим најфреквентније реакције остале непромењене. Самим тим можемо говорити о стабилном централном и периферном варијабилном пољу језгра језичке свести.

Стабилно поље чини првих пет најфреквентнијих реакција. У нашем случају од тих пет, четири су подударне у оба експеримента, то су: човек, срећа, љубав, живот. Из тога следи да је централни део језгра стабилан и да су опште људске вредности очувале своје место и значај у свести Срба у наведеном периоду. Потврда о стабилности централног поља језгра и ван језичке слике Срба, нашле смо и у реконструисаним језгрима језичке свести четири друга словенска народа, чије су асоцијације обухваћене Словенским асоцијативним речникомруског, белоруског, украјинског и бугарског језика.

Највеће разлике између језгара језичке свести Срба из два наведена периода, а самим тим и у концептуализацији JCC, уочљиве су у периферном варијабилном пољу језгра, односно у преосталих 25 реакција од 30 најфреквентнијих асоцијација. Размимоилажење се запажа у броју негативно конотираних асоцијација, које су израз „мрачније” JCC из 2003. године. Навешћемо неке од њих: досада, ништа, страх, глупост, лаж, рат, смрт, туга, лоше, бол. Са друге стране, у експерименту из 2020. јављају се бројне позитивне асоцијације, претежно везане за природу које указују на „ведрију” језичку слику света, међу њима су: сунце, дан, вода, дрво, снег, ноћ. Промене у варијабилном пољу језгра језичког сазнања сведоче о динамици промена у језичкој слици стварности кроз призму вербалних асоцијација.

Овим је постављена хипотеза потврђена, те је доказано да је језгро језичке свести, односно 30 најфреквентнијих реакција, подложно променама с годинама, због чега је неопходно периодично обнављати асоцијативне експерименте како би подаци асоцијативних речника били валидни за научна истраживања. Овде се поставља и питање оптималног периода за понављање асоцијативног експеримента, које, међутим, препуштамо будућим истраживањима.

Резултати аутентичног асоцијативног експеримента из 2020, чији фрагмент наводимо у Прилогу овом раду, могу бити полазиште за даља лингвокултуролошка, етнолингвистичка и когнитивнолингвистичка истраживања усмерена на проучавање динамике промена у колективним асоцијацијама, како у оквиру проучавања ЈСС Срба, тако и из контрастивног аспекта. 


\section{Цитирана литература}

Авагјан, Карина. Стереотип странца у језичкој слици стварности Руса и Срба (докторска дисертација). Београд: Филолошки факултет, 2017.

[Avagjan, Karina. Stereotip stranca u jezičkoj slici stvarnosti Rusa i Srba (doktorska disertacija). Beograd: Filološki fakultet, 2017]

Бартмињски, Јежи. Језик - слика - свет. Београд: SlovoSlavia, 2011.

[Bartminjski, Ježi. Jezik - slika - svet. Beograd: SlovoSlavia, 2011]

Даути, Менсел. „Етноними у мрежи вербалних асоцијација“.Славистика XVI, 2012: 617-631.

[Dauti, Mensel. „Etnonimi u mreži verbalnih asocijacija“. Slavistika XVI, 2012: 617-631]

Драгићевић, Рајна. „Нека запажања о могућности употребе асоцијативних тестова у Лингвистичким истраживањима”. Славистика VI, 2002, 116-124.

[Dragićević, Rajna. „Neka zapažanja o mogućnosti upotrebe asocijativnih testova u Lingvističkim istraživanjima“. Slavistika VI, 2002: 116-124]

Драгићевић, Рајна. „Асоцијативна метода у концептуализацији емоција” [У:] М. Совиљ (ур.) Говор и језик. Београд: Институт за експерименталну фонетику и патологију говора, 2003, 66-74.

[Dragićević, Rajna. „Asocijativna metoda u konceptualizaciji emocija”. [U:] M. Sovilj (ur.) Govor i jezik. Beograd: Institut za eksperimentalnu fonetiku i patologiju govora, 2003, 66-74]

Драгићевић, Рајна. Вербалне асоцијације кроз српски језик и културу. Београд: Друштво за српски језик и књижевност Србије, 2010.

[Dragićević, Rajna. Verbalne asocijacije kroz srpski jezik i kulturu. Beograd: Društvo za srpski jezik i književnost Srbije, 2010]

Кончаревић, Ксенија. „Индикатори религиозности у вербално-асоцијативној мрежи руског и српског језика”, Зборник Матице српске за славистику 87, 2015: $25-48$.

[Končarević, Ksenija. „Indikatori religioznosti u verbalno-asocijativnoj mreži ruskog i srpskog jezika” Zbornik Matice srpske za slavistiku 87, 2015: 25-48]

Кончаревић, Ксенија. „Религиозност кроз призму вербалних асоцијација носилаца српског језика”. Српски језик XX, 2015a: 79-93.

[Končarević, Ksenija. „Religioznost kroz prizmu verbalnih asocijacija nosilaca srpskog jezika". Srpski jezik XX, 2015: 79-93]

Пауновић Родић, Стефана. Стереотип жене у језичкој слици света Словака и Срба (докторска дисертација). Београд: Филолошки факултет, 2019.

[Paunović Rodić, Stefana. Stereotip žene u jezičkoj slici sveta Slovaka i Srba (doktorska disertacija). Beograd: Filološki fakultet, 2019]

Пипер, Предраг. „О проучавањима вербалних асоцијација”. [У:] М. Совиљ (ур.) Говор и језик. Београд: Институт за експерименталну фонетику и патологију говоpa, 2003, 55-65.

[Piper, Predrag. „O proučavanjima verbalnih asocijacija”. [U:] M. Sovilj (ur.) Govor I jezik. Beograd: Institut za eksperimentalnu fonetiku i patologiju govora, 2003, 55-65]

Пипер, Предраг. „О когнитивнолингвистичким и сродно усмереним проучавањима српског језика". [У:] П. Пипер (ур.) Когнитивнолингвистичка проучавања српског језика. Београд: САНУ, 2006, 9-46. 
[Piper, Predrag. „O kognitivnolingvističkim i srodno usmerenim proučavanjima srpskog jezika". [U:] P. Piper (ur.) Kognitivnolingvistička proučavanja srpskog jezika. Beograd: SANU, 2006, 9-46]

Поповић, Људмила. Језичка слика стварности. Когнитивни аспект контрастивне анализе. Београд: Филолошки факултет, 2008.

[Popović, Ljudmila. Jezička slika stvarnosti. Kognitivni aspekt kontrastivne analize. Beograd: Filološki fakultet, 2008]

Поповић, Људмила. „О актуелним когнитивнолингвистичким проучавањима српског језика”. Јужнословенски филолог 73/3-4, 2017: 315-354.

[Popović, Ljudmila. „O aktuelnim kognitivnolingvističkim proučavanjima srpskog jezika”. Južnoslovenski filolog. 73/3-4, 2017: 315-354]

Раздобудко-Човић, Лариса. „Културолошка и комуниколошка представа света на примерима руско-српских поредбених конструкција”. Зборник радова Филозофског факултета у Приштини XXXVI, 2006: 433-450.

[Razdobudko-Čović, Larisa. „Kulturološka i komunikološka predstava sveta na primerima rusko-srpskih poredbenih konstrukcija". Zbornik radova Filozofskog fakulteta u Prištini XXXVI, 2006: 433-450]

Ристић, Стана, Лазић Коњик, Ивана. Когнитивни правац у српској етнолингвистици - почеци развоја и актуелни проблеми. Београд: Институт за српски језик CAHУ, 2020.

[Ristić, Stana, Lazić Konjik, Ivana. Kognitivni pravac u srpskoj etnolingvistici počeci razvoja i aktuelni problemi. Beograd: Institut za srpski jezik SANU, 2020]

Стефановић, Марија. „Језик о породици: муж и жена у асоцијативним речницима руског и српског језика”. Славистика XII, 2008: 235-242.

[Stefanović, Marija. ,Jezik o porodici: muž i žena u asocijativnim rečnicima ruskog i srpskog jezika". Slavistika XII, 2008: 235-242]

Стефановић, Марија. Језичка слика породице у руском и српском језику. Нови Сад: Филозофски факултет, 2012.

[Stefanović, Marija. Jezička slika porodice u ruskom i srpskom jeziku. Novi Sad: Filozofski fakultet, 2012]

Стефановић, Марија. „Црква у асоцијативном систему српског језика”. [У:] J. Грковић Мејџор, К. Кончаревић (ур.) Теолингвистичка проучавања словенских језика. Београд: САНУ, 2013, 285-294.

[Stefanović, Marija. „Crkva u asocijativnom sistemu srpskog jezika”. [U:] J. Grković Mejdžor, K. Končarević (ur.) Teolingvistička proučavanja slovenskih jezika. Beograd: SANU, 2013, 285-294]

Стефановић, Марија. „О дометима експерименталних метода у опису језичке слике света: асоцијативно поље као извор података (на материјалу стимулуса ХЛЕБ у руском и српском језику)". Зборник Матице српске за филологију и лингвистику LVIII/2, 2015: 65-84.

[Stefanović, Marija. „O dometima eksperimentalnih metoda u opisu jezičke slike sveta: asocijativno polje kao izvor podataka (na materijalu stimulusa HLEB u ruskom i srpskom jeziku)". Zbornik Matice srpske za filologiju i lingvistiku LVIII/2, 2015: 65-84] 


\section{Извори}

Драгићевић, Рајна, Предраг Пипер, Марија Стефановић. Обратни асоцијативни речник српскога језика: II део, од реакције ка стимулусу. Београд: Београдска књига, Службени лист СЦГ, Филолошки факултет, 2011.

[Dragićević, Rajna, Predrag Piper, Marija Stefanović. Obratni asocijativni rečnik srpskoga jezika: II deo, od reakcije ka stimulusu. Beograd: Beogradska knjiga, Službeni list SCG, Filološki fakultet, 2011]

Балтова, П., А. Ефтимова, А. Липовска, К. Петрова. Български асоциативен речник, прав и обратен, София : Университет „Св. Климент Охридски“, Руска академия на науките, 2003.

[Baltova, P., A. Eftimova, A. Lipovska, K. Petrova. Balgarski asotsiativen rechnik, prav i obraten, Sofiya : Universitet „Sv. Kliment Ohridski“, Ruska akademiya na naukite, 2003]

Бутенко, Ніна. Словник асоциативних означень именникив в украинскии мови, Львів, 1989.

[Butenko, Nina. Slovnik asociativnih označen' imennikiv v ukrainskii movi, L'vìv, 1989]

Караулов, Юрий Н., Юрий А. Сорокин, Евгений Ф. Тарасов. Наталья В. Уфимцева, Галина А. Черкасова. Русский ассоциативный словарь. Москва: 1994, 1996, 1998.

[Karaulov, Urij N., Urij A. Sorokin, Evgenij F. Tarasov. Natal'â V. Ufimceva, Galina A. Čerkasova. Russkij associativnyj slovar'. Moskva: 1994, 1996, 1998]

Караулов, Юрий Н., Г.А. Черкасова, Н.В. Уфимцева [и др.]. Русский ассоциативный словарь: [В 2 т.]. Рос. акад. наук. - М. : АСТ : Астрель, 2002.

[Karaulov, Ûrij N., G.A. Čerkasova, N.V. Ufimceva [i dr.]. Russkij associativnyj slovar': [V 2 t.]. Ros. akad. nauk. - M. : AST : Astrel', 2002]

Мартінек, Світлана. Український асоціативний словник: від стимулу до реакції. Львів: Видавничий центр ЛНУ імені Івана Франка, 2007.

[Martìnek, Svitlana. Ukraïns'kij asocìativnij slovnik: vìd stimulu do reakciï. L'vìv: Vidavničij centr LNU ìmenì İvana Franka, 2007]

Пипер, Предраг, Рајна Драгићевић, Марија Стефановић. Асоцијативни речник српског језика. I део, од стимулуса ка реакцији. Београд: Београдска књига, Службени лист СЦГ, Филолошки факултет, 2005.

[Piper, Predrag, Rajna Dragićević, Marija Stefanović. Asocijativni rečnik srpskog jezika. I deo, od stimulusa ka reakciji. Beograd: Beogradska knjiga, Službeni list SCG, Filološki fakultet, 2005]

Уфимцева, Наталья В., Галина А.Черкасова, Юрий Н. Караулов, Евгений Ф. Тарасов. Славянский ассоциативный словарь: русский, белорусский, болгарский, украинский. Москва: Министерство образования и науки Российской Федерации, Московский государственный лингвистический университет, Российская академия наук, Институт языкознания, 2004.

[Ufimceva, Natal'â V., Galina A.Čerkasova, Uriij N. Karaulov, Evgenij F. Tarasov. Slavânskij associativnyj slovar': russkij, belorusskij, bolgarskij, ukrainskij. Moskva: Ministerstvo obrazovaniâ i nauki Rossijskoj Federacii, Moskovskij gosudarstvennyj lingvističeskij universitet, Rossijskaâ akademiâ nauk, Institut âzykoznaniâ, 2004]

Цітова, Алена. Асацыятыуны слоуник беларускай мовы, Мінск: Добровольский, Д.О. и Ю. Н. Караулов, 1981. 
[Citova, Aliena. Asacyjatyuny slounuk bielaruskaj movy, Minsk: Dobrovoĺskиj, D.O. и Ju. N. Karaulov, 1981]

Kurcz, Ida. Polskie normy powszechnosci skojarzen swobodnych na 100 slow z listy Kent-Rosanoffa, Wroclaw-Krakow: Studia psychologiczne III, 1967.

\section{Прилог 1}

\begin{tabular}{|c|c|c|c|}
\hline $\begin{array}{c}\text { Ситмулус и } \\
\text { најфреквентније }^{10} \\
\text { реакције из } 2003 .\end{array}$ & $\begin{array}{c}\text { Стимулус и } \\
\text { најфреквентније } \\
\text { реакције из } 2020 .\end{array}$ & $\begin{array}{c}\text { Негативно } \\
\text { конотиране } \\
\text { реакције на } \\
\text { стимулус из } 2003 .\end{array}$ & $\begin{array}{c}\text { Негативно } \\
\text { конотиране } \\
\text { реакљције на } \\
\text { стимулус из } 2020 .\end{array}$ \\
\hline $\begin{array}{l}\text { Бео } \\
\text { снег 216; црн 84; } \\
\text { град 52; чист 27; } \\
\text { зид 20; облак 17; }\end{array}$ & $\begin{array}{l}\text { бео } \\
\text { снег 180; град 106; } \\
\text { црн 58; зид, чист } \\
30 ; \text { облак } 25\end{array}$ & $\begin{array}{l}\text { бео } 48^{11} \\
\text { мртав 13; блед } \\
6, \text { смрт 5; болест } \\
3 ; \text { болестан; пра- } \\
\text { зно 2; анемичан, } \\
\text { антипатичан, авет, } \\
\text { бледуњав, бол, } \\
\text { болница, досада, } \\
\text { и мртав, јадан, } \\
\text { лудница, мртав } \\
\text { човек, на самрти, } \\
\text { наркоман, нервоза, } \\
\text { пази се, страх } 1\end{array}$ & $\begin{array}{l}\text { бео } 7 \\
\text { мртав 3, болест, } \\
\text { болестан, болница, } \\
\text { смрт } 1\end{array}$ \\
\hline $\begin{array}{l}\text { Говорити } \\
\text { причати 174; ћутати } \\
49 ; \text { језик } 30 \text {; брбља- } \\
\text { ти } 29 ; \text { уста } 27 \text {; }\end{array}$ & $\begin{array}{l}\text { говорити } \\
\text { истину } 83 \text {; причати } \\
83 \text {; речи } 42 ; \text { глас } \\
27 \text {; језик 26; гласно } \\
24 ;\end{array}$ & $\begin{array}{l}\text { говорити } 100 \\
\text { брбљати 29; } \\
\text { глупости 11; бла } \\
\text { бла, блебетати, } \\
\text { досађивати, } \\
\text { глупост, лагати 4; } \\
\text { паметовати 3; бити } \\
\text { досадан, брбљив, } \\
\text { досада, тртљати, у } \\
\text { празно 2; а ништа } \\
\text { не рећи, бла бла } \\
\text { бла, брбљање, } \\
\text { брбљивац, } \\
\text { брбљивица, }\end{array}$ & $\begin{array}{l}\text { говорити } 31 \\
\text { глупости 13; } \\
\text { лажи 9; досада 2; } \\
\text { викати; гњавити; } \\
\text { драти се; лагати; } \\
\text { придиковати; у } \\
\text { празно; узалуд } 1\end{array}$ \\
\hline
\end{tabular}

${ }^{10}$ Поље са најфреквентнијим реакцијама обухвата асоцијације које се као фреквентне поклапају у оба речника, нпр. стимулус бео, или, уколико то није случај, последња реакција коју смо навеле у пољу најфреквентнијих реакција на задати стимулус је она након које следи реакција са знатно мањом фреквентношћу у АП, нпр. љуббав (2020): срие (78) срећа (74) породииа (45) - живот (25) дете/деца (20) мржња (18) брак (14), итд.

${ }^{11}$ Укупан број негативних реакција које су се јавиле на задати стимулус 


\begin{tabular}{|c|c|c|c|}
\hline & & $\begin{array}{l}\text { бука, дангубити, } \\
\text { давити, главобоља, } \\
\text { глупо, кокошка, } \\
\text { лажи, лупати, } \\
\text { не, нервирати, } \\
\text { олајавати, } \\
\text { пљувати, превише, } \\
\text { страх, торокати, } \\
\text { трабуњати, } \\
\text { трачарити, трачеви, } \\
\text { узалуд, викати, } \\
\text { замарати, замор } 1\end{array}$ & \\
\hline $\begin{array}{l}\text { љубав } \\
\text { срећа } 88 ; \text { срце } 60 ; \\
\text { мржња 29; }\end{array}$ & $\begin{array}{l}\text { љубав } \\
\text { срце } 78 ; \text { срећа } 74 ; \\
\text { породица } 45 ;\end{array}$ & $\begin{array}{l}\text { љубав } 63 \\
\text { мржња 29; бол, } \\
\text { глупост, илузија 3; } \\
\text { не постоји, непо- } \\
\text { знато, патња, смрт, } \\
\text { сузе, туга 2; апсурд, } \\
\text { катастрофа, лаж, } \\
\text { љубомора, НАТО, } \\
\text { не,не знам, недо- } \\
\text { кучиво, неимање, } \\
\text { немогућа, несрећа, } \\
\text { неузвраћена, невер- } \\
\text { ство, није вечна, } \\
\text { ретко, реткост, умр- } \\
\text { ла је, усамљеност, } \\
\text { варка 1; }\end{array}$ & $\begin{array}{l}\text { љубав } 45 \\
\text { мржња 18; лаж, } \\
\text { рат, туга 3; бол, } \\
\text { брига, не знам } \\
2 ; \text { бајка, драма, } \\
\text { заблуда, илузија, не } \\
\text { постоји, небитна, } \\
\text { непостојећа, } \\
\text { патња, прецењена, } \\
\text { пролазно, реткост, } \\
\text { смрт 1; }\end{array}$ \\
\hline $\begin{array}{l}\text { муж⿻ } \\
\text { жена 210; брак } 88 \text {; } \\
\text { љубав } 38 ; \text { супруг } \\
35 \text {; отац 24; човек, } \\
\text { породица 23; пуж } \\
22 ;\end{array}$ & $\begin{array}{l}\text { мужс } \\
\text { жена } 121 \text {; брак } 74 ; \\
\text { љубав 46; отац } 38 ; \\
\text { пуж } 30 ;\end{array}$ & $\begin{array}{l}\text { мужс } 74 \\
\text { обавеза 13; } \\
\text { љубавник 7; далеко } \\
\text { 5; досада, швалер } \\
3 \text {; брига, будала, } \\
\text { никад, роб, смор, } \\
\text { терет 2; алкохол, } \\
\text { богаташ, црно, } \\
\text { далеко је то, } \\
\text { даљина, дебео, } \\
\text { фуј,геј, господар } \\
\text { жене, гунђање, } \\
\text { издаја, издајица, } \\
\text { јој не, лош, мука, } \\
\text { напор, не сад, } \\
\text { неизвесност, } \\
\text { немуж, неслобода, } \\
\text { нешто далеко, } \\
\text { неверан, обавезе, }\end{array}$ & $\begin{array}{l}\text { муж⿻ } 54 \\
\text { обавеза, швалер } \\
3 \text {; ауторитет, бес, } \\
\text { геј, досада, лењ, } \\
\text { лењост, лош, туђ 2; } \\
\text { бивши, брига, газда, } \\
\text { гроб, давеж, далеко, } \\
\text { ерор 404, идиот, } \\
\text { издаја, љубавница, } \\
\text { коњ, конкуренција, } \\
\text { кретен, магарац, } \\
\text { милионер, мученик, } \\
\text { напаст,напор, } \\
\text { насиље, } \\
\text { неспоразум, никад, } \\
\text { пакао, папучар, } \\
\text { пијан, превара, } \\
\text { проблем, смарач, } \\
\text { снабдевен, }\end{array}$ \\
\hline
\end{tabular}




\begin{tabular}{|c|c|c|c|}
\hline & & $\begin{array}{l}\text { осуда, отров, } \\
\text { папуча, пропаст, } \\
\text { смарач, старост, } \\
\text { стереотип, страх, } \\
\text { странац, свађа, } \\
\text { вишак, заблуда, } \\
\text { заборављеност, } \\
\text { затвор 1; }\end{array}$ & $\begin{array}{l}\text { социјални концепт, } \\
\text { стереотип, } \\
\text { формалност, хладан } \\
1 ;\end{array}$ \\
\hline $\begin{array}{l}\text { надати се } \\
\text { желети } 64 \text {; очекива- } \\
\text { ти 52; веровати 44; } \\
\text { чекати } 37 \text {; срећа } 31 ; \\
\text { нечему } 27 \text {; }\end{array}$ & $\begin{array}{l}\text { надати се } \\
\text { вера 53; веровати } \\
52 ; \text { жеља } 35 ; \\
\text { желети } 33 ; \\
\text { очекивати } 29 ; \\
\text { бољем } 28 ; \text { чекати } \\
27 ;\end{array}$ & $\begin{array}{l}\text { надати се } 86 \\
\text { узалуд 18; не } \\
\text { надати се, стрепети } \\
4 ; \text { узалудно 3; губи- } \\
\text { ти време, изгубити, } \\
\text { лагати се, неиз- } \\
\text { весност,разочара- } \\
\text { тисе,разочарење, } \\
\text { варати се, завара- } \\
\text { вати се 2; бити луд, } \\
\text { бојати се, будала, } \\
\text { ћорсокак, главобо- } \\
\text { ља, Годоу, губити, } \\
\text { губити наду, } \\
\text { и надати и надати, } \\
\text { имати илузију, из- } \\
\text { губити наду, кајати } \\
\text { се, лагати, лагати } \\
\text { себе, лажна нада, } \\
\text { лажно, не, нервоза, } \\
\text { несигурност, ни- } \\
\text { чему, патити, плач, } \\
\text { прибојавати , при- } \\
\text { бојавати се, разоча- } \\
\text { рање, разочарати, } \\
\text { смрт, сузе, трошити } \\
\text { време, туга, умо- } \\
\text { рити се, умрети, } \\
\text { узалудно чекање, } \\
\text { узалудност, } \\
\text { венути, зебња, зе- } \\
\text { знути, злопатити се, } \\
\text { живети у лажи 1; }\end{array}$ & $\begin{array}{l}\text { надати се } 86 \\
\text { узалуд 17; стрепња, } \\
\text { туга 5; болест, } \\
\text { глупост, лагати } \\
\text { се, разочарати } \\
\text { се, разочарење } \\
\text { 3; безнадежно, } \\
\text { бити глуп, будала, } \\
\text { несигурност, } \\
\text { неуспешно, патити, } \\
\text { смрт, стрепети, џабе } \\
\text { 2; безнадежност, } \\
\text { безнађе, } \\
\text { беспотребно, брига, } \\
\text { будалаштина, } \\
\text { губити, заблуда, } \\
\text { зебња, илузија, } \\
\text { имагинација, } \\
\text { лоше, лаж, не } \\
\text { вреди, не надати } \\
\text { се, неизвесност, } \\
\text { неискрено, } \\
\text { неостварење, } \\
\text { непријатност, } \\
\text { ничему, одустати, } \\
\text { падати, празно, } \\
\text { пропасти, рањивост } \\
\text { распад, страх 1; }\end{array}$ \\
\hline $\begin{array}{l}\text { обећање } \\
\text { лудом радовање } \\
\text { 108; испуњење } 57 \text {; } \\
\text { реч 40; радовање } \\
36 \text {; лаж } 32 ; \text { обавеза } \\
\text { 30; нада } 21\end{array}$ & $\begin{array}{l}\text { обећати } \\
\text { испунити 192; реч } \\
39 ; \text { (с)лагати } 22 ; \\
\text { поверење } 21 ; \text { дати } \\
\text { реч 19; лаж } 16\end{array}$ & $\begin{array}{l}\text { обећање } 232 \\
\text { лудом радовање } \\
\text { 108; лаж } 32 ; \text { лудо } \\
\text { радовање 11; лудост } \\
\text { 7; неиспуњено 7; } \\
\text { лажно 6; }\end{array}$ & $\begin{array}{l}\text { обећати } 88 \\
\text { слагати 22; лаж } \\
\text { 16; лагати 5; } \\
\text { прекршити 5; } \\
\text { неиспуњење 4; } \\
\text { никад, празно, }\end{array}$ \\
\hline
\end{tabular}




\begin{tabular}{|c|c|c|c|}
\hline & & $\begin{array}{l}\text { неиспуњење 5; } \\
\text { кршере 3; луд, } \\
\text { лудак, не испунити, } \\
\text { немогуће, празно, } \\
\text { прекршај, пусто } \\
\text { радовање, сумња, } \\
\text { узалудно 2; џабе; } \\
\text { илузије; изневера; } \\
\text { извлачење; не } \\
\text { држи; кривица; } \\
\text { ‘ладно; лагање; } \\
\text { лажан; лажно } \\
\text { радовање; лудо; } \\
\text { лудо веровати; } \\
\text { лудом; ма дај; } \\
\text { мржњу; напетост; } \\
\text { не одржавају; } \\
\text { не ослањати } \\
\text { се; небитно; } \\
\text { неповерење; } \\
\text { нестаје; неверност; } \\
\text { никада; одгађање; } \\
\text { ограничење; } \\
\text { превара; прича у } \\
\text { празно; протраћено; } \\
\text { пусто; разочарање, } \\
\text { страх; узалуд; } \\
\text { уздрманост; } \\
\text { заблуда; заборавити } \\
1\end{array}$ & $\begin{array}{l}\text { разочарање } 3 ; \\
\text { заборавити, } \\
\text { лудом радовање, } \\
\text { не испунити, } \\
\text { немогуће, } \\
\text { разочарати , терет } \\
2 \text {; бол; зебња } \\
\text { издаја; изневерити; } \\
\text { коцка; лагати } \\
\text { себе; луд; лудак; } \\
\text { несклад; обмана; } \\
\text { опрезно; прекршај; } \\
\text { притисак; сувишно; } \\
\text { тежина; узалудно; } \\
\text { шипак } 1\end{array}$ \\
\hline $\begin{array}{l}\text { појести } \\
\text { ручак, сендвич 62; } \\
\text { храна 49; колач 43; } \\
\text { јабуку 29; чокола- } \\
\text { ду 27; }\end{array}$ & $\begin{array}{l}\text { јести } \\
\text { храну 143; пити 26; } \\
\text { глад } 21 \text {; хлеб 18; } \\
\text { потреба 15; ручак } \\
13 ;\end{array}$ & $\begin{array}{l}\text { појести } 62 \\
\text { глад 15; гладан, } \\
\text { говно 4; дебео, } \\
\text { дијета, угојити } \\
\text { се 3; гладовати, } \\
\text { гојазност, } \\
\text { килограми 2; алав, } \\
\text { буђ, буђу, дебљина, } \\
\text { дијареја, гладна, } \\
\text { говна, измета, јао } \\
\text { глад, калорија, } \\
\text { морање, не, не } \\
\text { јести, отровно, } \\
\text { обавеза, обмана, } \\
\text { огладнети,пљунути, } \\
\text { покајати се, } \\
\text { превише, }\end{array}$ & $\begin{array}{l}\text { jeсти } 61 \\
\text { глад 21; гладан 8; } \\
\text { гладовати 4; гојити } \\
\text { се, дебео, морати } \\
\text { 3; бљак, брига, } \\
\text { гојазан, гојазност, } \\
\text { гојење, дијета, } \\
\text { досада, жељан, } \\
\text { морање, мука, } \\
\text { обавеза, опсесија, } \\
\text { повраћати, } \\
\text { превише, } \\
\text { претеривати, страх, } \\
\text { тежина, тешкоћа, } \\
\text { уф 1; }\end{array}$ \\
\hline
\end{tabular}




\begin{tabular}{|c|c|c|c|}
\hline & & $\begin{array}{l}\text { прождрати, се жив, } \\
\text { себе 1; }\end{array}$ & \\
\hline $\begin{array}{l}\text { праведан } \\
\text { суд 65; човек 59; } \\
\text { поштен, судија 57; } \\
\text { добар 49; искрен } \\
\text { 42; неправедан 27; } \\
\text { исправан 24; }\end{array}$ & $\begin{array}{l}\text { правда } \\
\text { суд } 153 ; \text { истина } 80 ; \\
\text { неправда } 48 ; \text { бог, } \\
\text { закон } 23 ; \text { вага } 20 ;\end{array}$ & $\begin{array}{l}\text { праведан } 92 \\
\text { неправедан 27; } \\
\text { реткост 7; } \\
\text { не постоји 4; ни- } \\
\text { ко 3; } \\
\text { будала, глуп, лажан, } \\
\text { наиван, неправда, } \\
\text { релативно 2; } \\
\text { без новца, циција, } \\
\text { говедар, идиот, илу- } \\
\text { зија, илузије, истро- } \\
\text { шен, издан, изго- } \\
\text { вор, једноличан, } \\
\text { крив, лицемеран, } \\
\text { лош, луд, } \\
\text { недокучиво, нема } \\
\text { таквог, немоћ, не- } \\
\text { поштен, непознато, } \\
\text { несхваћен, никад, } \\
\text { нож, нула, окру- } \\
\text { тан, оштар, патња, } \\
\text { педер, поремећен, } \\
\text { празнина, превара, } \\
\text { приведен, редак, } \\
\text { ретко ко, рогови, } \\
\text { сиромашан, слеп, } \\
\text { смрад, суров, } \\
\text { штребер 1; }\end{array}$ & $\begin{array}{l}\text { правда } 112 \\
\text { неправда 48; } \\
\text { нема је 13; } \\
\text { непостојећа 9; не } \\
\text { постоји 8; слепа 5; } \\
\text { реткост 4; тешка 2; } \\
\text { бајка, будала, } \\
\text { далеко, злочин, } \\
\text { издаје, измакла, } \\
\text { илузија, } \\
\text { имагинација, } \\
\text { инат, неједнакост, } \\
\text { немогуће, } \\
\text { неостварена, } \\
\text { непознат појам, } \\
\text { несигурна, } \\
\text { неспокој, } \\
\text { озлојеђеност, } \\
\text { осуђеник, премало, } \\
\text { пуста жеља, } \\
\text { слабост, слепоћа, } \\
\text { смрад, спорост 1; }\end{array}$ \\
\hline $\begin{array}{l}\text { радост } \\
\text { срећа } 301 ; \text { туга } 61 ; \\
\text { љубав } 36 ; \text { сунце } \\
29 ; \text { осмех, смех } 23 \text {; } \\
\text { дете } 22 ;\end{array}$ & $\begin{array}{l}\text { радост } \\
\text { срећа } 238 ; \text { осмех } \\
\text { 39; весеље } 32 ; \text { дете } \\
31 \text {; туга } 30 ; \text { деца } 27 ;\end{array}$ & $\begin{array}{l}\text { радост } 83 \\
\text { туга 61; жалост 11; } \\
\text { болан; бол; дрога; } \\
\text { гадост; } \\
\text { мало; не постоји; } \\
\text { неискреност; нема } \\
\text { је; пролаз; страх; } \\
\text { заборав } 1\end{array}$ & $\begin{array}{l}\text { paдосm } 36 \\
\text { туга } 30 ; \text { гадост; } \\
\text { жалост; кратка; } \\
\text { краткорочност; } \\
\text { несрећа } 1\end{array}$ \\
\hline $\begin{array}{l}\text { родбина } \\
\text { породица 56; фами- } \\
\text { лија 41; тетка 32; } \\
\text { пријатељи 30; рођа- } \\
\text { ци 29; }\end{array}$ & $\begin{array}{l}\text { родбина } \\
\text { породица 103; } \\
\text { слава 54; блискост, } \\
\text { окупљање } 31 ;\end{array}$ & $\begin{array}{l}\text { родбина } 104 \\
\text { доасада 17; далеко } \\
\text { 6; смор 5; далека, } \\
\text { гужва, свађа 4; } \\
\text { бука, даљина, } \\
\text { досадна, досадно, } \\
\text { гомила, напаст, } \\
\text { напор, обавеза, } \\
\text { обавезе, }\end{array}$ & $\begin{array}{l}\text { родбина } 95 \\
\text { досадна 14; даљина } \\
\text { 13; обавеза 9; } \\
\text { обавезе 4; досада, } \\
\text { одбаченост, } \\
\text { отуђеност, пакао, } \\
\text { свађа 3; гласна, } \\
\text { издаја, лоша, } \\
\text { неблиска, }\end{array}$ \\
\hline
\end{tabular}




\begin{tabular}{|c|c|c|c|}
\hline & & $\begin{array}{l}\text { сахрана, смарачи, } \\
\text { сморови 2; давежи, } \\
\text { дављење, дебили, } \\
\text { досадне будале, } \\
\text { галама, гњавежи, } \\
\text { издајица, кокошке, } \\
\text { лаж, лажњива, } \\
\text { луђаци, љубомора, } \\
\text { магловито, маторци, } \\
\text { мржња, наметнута, } \\
\text { не бираш, не } \\
\text { ваља, недостатак, } \\
\text { неискреност, } \\
\text { немогућност } \\
\text { избора, } \\
\text { неповезаност, } \\
\text { непознати, } \\
\text { непријатељ, } \\
\text { незаинтересован, } \\
\text { оптерећење, } \\
\text { отуђеност, празно, } \\
\text { превише, проблем, } \\
\text { сумњиво, свраб, } \\
\text { штета, туђа, } \\
\text { туђина, удаљеност, } \\
\text { уплакана, зона } \\
\text { сумрака 1; }\end{array}$ & $\begin{array}{l}\text { незахвална, упомоћ } \\
\text { 2; брига, бука, } \\
\text { завађена, зло, } \\
\text { избегавање, лаж, } \\
\text { љубомора, метеж, } \\
\text { мука, неизабрана, } \\
\text { неискрена, } \\
\text { непријатељи, } \\
\text { неразумевање, } \\
\text { несигурност, } \\
\text { ништавило, } \\
\text { нужно зло, о } \\
\text { не, покварена, } \\
\text { проблеми, } \\
\text { раздвојеност, } \\
\text { сахрана, сујета, } \\
\text { терет, трач, } \\
\text { трачарење, фуј, } \\
\text { хаос, циркус 1; }\end{array}$ \\
\hline \multirow[t]{2}{*}{$\begin{array}{l}\text { cpeћa } \\
\text { несрећа 85; радост } \\
75 ; \text { љубав 69; } \\
\text { осмех, успех 22; } \\
\text { здравље 21; туга, } \\
\text { задовољство, живот } \\
\text { 20; }\end{array}$} & $\begin{array}{l}\text { срећа } \\
\text { радост 102; љубав } \\
52 ; \text { породица 48; } \\
\text { осмех } 39 ; \text { туга 27; } \\
\text { здравље 23; смех } \\
21 ; \text { несрећа 19; } \\
\text { детелина } 15 ;\end{array}$ & $\begin{array}{l}\text { cpeћa } 142 \\
\text { несрећа } 85 \text {; туга 20; } \\
\text { у несрећи } 10 ; \text { коцка; } \\
\text { лутрија; илузија; } \\
\text { реткост; баксуз; } \\
\text { ретка; релативност; } \\
\text { недостижна; } \\
\text { недостижност, } \\
\text { немам; невоља; }\end{array}$ & $\begin{array}{l}\text { cpeћa } 74 \\
\text { туга 27; несрећа } \\
\text { 19; кратка 5; } \\
\text { пролазност 3; } \\
\text { краткотрајна, } \\
\text { недостижност, сузе } \\
2 \text {; алкохол, баксуз, } \\
\text { измишљено, } \\
\text { лоша, лутрија, } \\
\text { недостижно, }\end{array}$ \\
\hline & & $\begin{array}{l}\text { незнање; пад; } \\
\text { имагинација; крш; } \\
\text { лудило; мука; } \\
\text { невоља; лаж; } \\
\text { привид; привидно; } \\
\text { пролазна; пун себе; } \\
\text { тешко остварљива; } \\
\text { тежина; заблуда; } \\
\text { жалост } 1\end{array}$ & $\begin{array}{l}\text { недоступност; } \\
\text { несталност; } \\
\text { нестварно; } \\
\text { неухватљивост, } \\
\text { патња, плач, } \\
\text { реткост, сујеверjе } 1\end{array}$ \\
\hline
\end{tabular}




\begin{tabular}{|c|c|c|c|}
\hline $\begin{array}{l}\text { црн } \\
\text { бео } 133 ; \text { црнац } 39 ; \\
\text { угаљ } 34 ; \text { човек, } \\
\text { мрак } 29 ;\end{array}$ & $\begin{array}{l}\text { црн } \\
\text { угаљ 56; ноћ 47; бео } \\
44 ; \text { мрак 31; гавран } \\
26 ;\end{array}$ & $\begin{array}{l}\text { црн } 121 \\
\text { мрак 29; гавран, } \\
\text { таман 16; мрачан } \\
\text { 12; смрт 6; туга } \\
6 \text {; ђаво 5; мрк 5; } \\
\text { тама 5; лош 2; } \\
\text { негативан 2; тамно } \\
\text { 2; метак; мука; } \\
\text { несрећа; несрећан; } \\
\text { нешто лоше; } \\
\text { од муке, пепео; } \\
\text { самоћа, суморан; } \\
\text { суморност; } \\
\text { тамнина; тмуран; } \\
\text { зао; жалост } 1\end{array}$ & $\begin{array}{l}\text { црн } 107 \\
\text { мрак } 31 \text {, смрт 16; } \\
\text { ђаво 12; туга 9; } \\
\text { мрачан 7; тама } 7 \\
\text {; лоше 6; мрачно } \\
6 \text {; прљав 5; враг; } \\
\text { гробље; несрећа; } \\
\text { несрећан сврака, } \\
\text { удовица; тмуран; } \\
\text { тумор } 1\end{array}$ \\
\hline \multirow[t]{2}{*}{$\begin{array}{l}\text { cmap } \\
\text { млад 139; деда } 138 ; \\
\text { човек 60; матор 29; } \\
\text { дека 22; старац 17; }\end{array}$} & $\begin{array}{l}\text { cmap } \\
\text { деда } 130 ; \text { млад } 75 ; \\
\text { човек 60; мудар 42; } \\
\text { дека 41; искусан 22; }\end{array}$ & $\begin{array}{l}\text { стар } 137 \\
\text { матор 29; смрт } \\
\text { 12; немоћан 8; } \\
\text { болестан 7; досадан } \\
5 ; \text { беспомоћан } \\
4 \text {; крај, немоћ, } \\
\text { уморан 3; болест, } \\
\text { истрошен, } \\
\text { изнемогао, леш, } \\
\text { непокретан, } \\
\text { оронуо, пролазност, } \\
\text { тужно 2; гроб, } \\
\text { грозан, изнемоћао, } \\
\text { јадан,јадник, јадно, } \\
\text { крхак, лењ, луд, } \\
\text { љигав, млохав, } \\
\text { на крају, не, не } \\
\text { желим, нема више, } \\
\text { немилосрдан, } \\
\text { непотребан, } \\
\text { несимпатично, } \\
\text { неупотребљив, }\end{array}$ & $\begin{array}{l}\text { cmap } 108 \\
\text { немоћан 19; слаб } \\
12 ; \text { беспомоћан, } \\
\text { болестан 7; } \\
\text { непокретан, пијан, } \\
\text { тужан, уморан } \\
\text { 4; дотрајао,крај, } \\
\text { искоришћен 3; } \\
\text { истрошен, оронуо, } \\
\text { смрт 2; } \\
\text { бол, болест, } \\
\text { бушан, времешан, } \\
\text { досада, зарђао, } \\
\text { изнемоглост, } \\
\text { крхак, мртав, на } \\
\text { крају, не, небитна, } \\
\text { незаштићеност, } \\
\text { нелагодност, } \\
\text { никако, оронулост, } \\
\text { погурен, смрт, } \\
\text { пролазност, } \\
\text { расходован, рђа, } \\
\text { сажаљење, слабост, }\end{array}$ \\
\hline & & $\begin{array}{l}\text { незадовољство, ни } \\
\text { за шта је, никакав, } \\
\text { одбачен, одрпан, } \\
\text { окорели, плач, } \\
\text { ружан, самоћа, } \\
\text { слаб, смежуран, } \\
\text { спор, спорост, туга, } \\
\text { тужан, узалудан, } \\
\text { задрт, згурен 1; }\end{array}$ & $\begin{array}{l}\text { слеп, смор, страх, } \\
\text { тром, трошан, } \\
\text { умирање, умишљен, } \\
\text { умрљан, усамљен 1; }\end{array}$ \\
\hline
\end{tabular}


Ваня Йованович, Мария Нисич, Анна Цветанович

\section{О ДИНАМИКЕ ИЗМЕНЕНИЙ В ЯЗЫКОВОЙ КАРТИНЕ МИРА СКВОЗЬ ПРИЗМУ СЛОВЕСНЫХ АССОЦИАЦИЙ (НА ПРИМЕРЕ СЕРБСКОГО ЯЗЫКА)}

\section{Резюме}

На основании материала, собранного исследователями в ходе ассоциативного эксперимента, проведенного студентами филологического факультета Белградского университета в 2020 г., и Ассочиативного словаря сербского языка (2003 г.) выполнен анализ состава так называемого ядра языкового сознания, которое представлено тридцатью наиболее частотными реакциями на заданные стимулы.

Исследователи исходили из предположения о том, что ассоциации претерпивают влияние обстоятельств общественной жизни, и в соответствии с этим был поставлен вопрос, насколько устойчивым явлется ядро языкового сознания.

В ответных реакциях, собранных во время обоих экспериментов, между которыми 17 лет, совпадают те, которые имеют отношение к общечеловеческим ценностям, тогда как различия возникли под влиянием актуальных общественных обстоятельств. В связи с коронавирусом и принудительной изоляцией в 2020 г. в ядре языкового сознания, реконструированного исходя из реакций этого периода, в основном представлены лексемы, имеющие отношение к природе, тогда как в 2003 году в сознании сербов, по-видимому, все еще хранилась память о недавних войнах, что объясняет частотность реакций с негативным подтекстом (страх, смерть, печаль, боль). Частотность реакций, вошедших в ядро языкового сознания, также указывает на определенное рангирование ценностей, анализу которого в работе посвящается особое внимание.

Ключевые слова: когнитивная лингвистика, словесные ассоциации, ассоциативный эксперимент, языковая картина мира, ядро языкового сознания. 